\title{
Contention Between Communalist and Capitalist Inhabitants Escort to the Cold War
}

\author{
Dr. Abdul Zahoor Khan, Ph.D. \\ Assistant Professor, Department of History \& Pakistan Studies \\ Faculty of Social Sciences, International Islamic University, Islamabad-Pakistan, \\ Phone Office: +92-51-9019517, Cell: +92-300-5527644, +92-300-7293535 \\ Emails:dr.zahoorkhan@iiu.edu.pk, ,dr.zahoorkhan@ymail.com
}

\section{Doi:10.5901/mjss.2013.v4n2p437}

\begin{abstract}
:
In retrospect, the question, (what was the cold war about?), seems to a great extent harder to answer than it probably did to contemporaries, some of whom would probably shake their head in wonderment at the above analysis. Yet if we address each of its putative justifications singly, any clear answer seems to fade into the ether. First, from the U.S. side, was the cold war about fighting communism? As long as the Soviet Union remained the sole Communist state, this was a fairly simple proposition, because communism and Russian/Soviet power amounted to the same thing. After 1948, however, with the emergence of independent centers of Communist power in Yugoslavia and then in China, the ideological simplicity of the cold war disappeared. The United States found itself supporting communism in its national variety precisely in order to complicate the projection of Soviet power. The Yugoslav case has been mentioned; and although the U.S. opening to China would be delayed by two, decades of tragic ideological blindness, the United States did undertake, after 1956, to encourage and cultivate national communism in Eastern Europe in the form of the policy of differentiation. Therefore, communism as such was not necessarily inimical to U.S. interests and cannot prove sufficient as an explanation for the course of the cold war.
\end{abstract}

Keywords:Cold-War, Panorama, Communalist and Capitalist, Marshall Plan, U.S.A., U.S.S.R., Khrushchev, Korean War, the Leninist "kto-kogo", Evil Empire, Nixon-stumbled, Martin Luther King, Jr., Brezhnev- Kosygin, Carter's triumph.

\section{Sequential Panorama}

What about the argument that the cold war revolved around the necessity to create a stable balance of power in Europe as against the disproportionate Soviet power presence there? Whereas this made up the core of the East-West conflict after the war, by the mid-1950s the economic health and political self-confidence of Western Europe always the focal point of the containment strategy in Europe had been restored, supplemented by NATO, the powerful trans-Atlantic military arm of the North Atlantic Treaty. Khrushchev himself admitted this basic fact in his 1956 revision of Soviet doctrine, in which he admitted the possibility of peaceful roads to socialism, and in the establishment of diplomatic relations with the Federal Republic of Germany in 1955. So if the cold .war continued past the mid-1950s, the need to establish a European balance of power was no longer a central issue in it. As for the position, central to West German foreign policy at the time, that the cold war was quintessentially about resolving the division of Germany in a divided Europe, the deeds of all sides would show, before the decade of the 1950s was out, their essential satisfaction with this de facto geopolitical settlement emerging out of World War II (Acheson 1969).

Although the containment of Russian/Soviet power, as distinct from communism as such, was certainly the centerpiece of U.S. cold war policy (though by the 1960s China had assumed higher priority for the United States), containment and cold war were not strictly synonymous. In Europe, at least, the task of containing Soviet power was adequately framed in terms of the Marshall Plan, a sober and pragmatic initiative that avoided the hyperbole and universalism characteristic of the cold war atmosphere of the 1950s. Even the North Atlantic Treaty, as distinct from NATO, was initially conceived as primarily a political undertaking. Only with the advent of the Korean War in June 1950 did the cold war assume the hyperbolic, militarized, and semi apocalyptic character that it has retained in the popular imagination. Significantly, powerful traces of this cold war atmosphere, transcending the specific issues for which the cold 
war was ostensibly fought, would survive their resolution and continue to haunt the present in the guise of mental images, military instruments, and institutional interests. The task of "managing" Soviet power, then, goes beyond the concept of cold war because (1) "cold war" was not originally considered requisite to that task, and (2) the task itself outlives the waning of the cold war.

Finally, was the cold war about the contest between capitalism and communism, or rather democracy and communism? Certainly, many thought so at the lime. Stillman and Pfaff captured this sense well when they wrote in 196l: "A Presidential proposal for a world referendum on the issue of Communism versus the American political system would in 1947 have seemed implausible if not impertinent. In 1960, when it was in fact made, it hardly seemed remarkable: the revolution in America's thinking during the decade was imposing (Stillman \& Pfaff 1961).

The prevailing atmosphere in East and West in the late 1950s was indeed one of civilizational challenge, as Khrushchev made clear with his "we will bury you" remark and as the Americans displayed in their frantic reaction to Sputnik. The problem is that it is practically impossible to relate such Spenglerian brooding (on the U.S. side) to any specific political agenda, save perhaps whether the newly independent nations would "go" Communist or not. This is not to discount such atmospherics, for they certainly played a role in reinforcing and inflaming existing sources of tension. The analytical difficulty is in relating the issue of domestic systems to the international political agenda: There is no strict and necessary relationship between the two and much evidence to suggest that regardless of the course of the two economic/political systems, there will remain plenty of sources of tension and conflict to keep diplomats and warriors gainfully employed for decades to come.

What then was the cold war about? And if it is not the cold war but the post-cold war order that is now ending, how is one to interpret the undeniable changes now buffeting the international political system?

In substantive terms the cold war played itself out long ago. The issues over which it was fought Germany, balance of power, deterrence of war, the relevance of U.S. and Soviet ideology to the Third World have been either effectively resolved or removed to the periphery of international political life. The one element that could not quite be removed, at least until the collapse of Soviet power itself in August 1991, is that of fear, fear of ultimate intentions and existing capabilities (mainly military). The images and military instruments generated by the cold war have outlived the cold war itself; yet although they no longer bear directly on negotiable political differences, they continue to exert their influence on contemporary international relations. The image of the "evil empire" advanced by President Reagan in 1983 which is really only the mirror image of the United States that the Soviet leadership had been trumpeting for so long, expresses this well and underscores the remarkable continuity of basic imagery from Dulles's time right through the 1980

The military dimension, claimed to be only the reflection of political differences, continued to occupy a prominent place in East-West relations well past the time when the central issues of contention, i.e., the division of Germany and of Europe and the establishment of a stable balance of power in Europe and East Asia, had been settled. So, although the cold war proper ended sometime during the 1960s, its presence has lingered via its residue of fear and the worst-case thinking that often appears the only prudent hedge against the fearful arsenals at the disposal of East and West. We may thus safely paraphrase Thucydides, cited in the chapter epigraph, and conclude that the real cause of the cold war (and of its continuation In attenuated form) has been the growth of U.S. power and the fear this caused in Russia; and conversely, the growth in Soviet power and the fear this caused in the United States.

But if the cold war proper ended long ago and its residue is largely the atmospherics it engendered, then how should we interpret the changes that have given rise to the query, Is the cold war over? Obviously, the breakthrough in East-West relations since 1986 has been generated by the domestic and foreign policy changes introduced by Soviet leader Mikhail Gorbachev and the general responsiveness of the West to them. Gorbachev came to power clearly intent upon liquidating those tendencies in Soviet foreign policy that had led to the growing isolation of the Soviet Union during the late Brezhnev era and beyond and that served to justify U.S. treatment of the Soviet Union as a pariah state(Dashichev 1988).What Gorbachev and his team did was to analyze key international trends that had been brewing for the preceding decade and more and to adapt Soviet foreign policy to their implications. These trends-include:

- The increased technological creativity and dynamism of the capitalist West, which has led to the information revolution and an ever- increasing economic gap with the West.

- The general intractability to change in the Third World.

- The progressive decrease of superpower influence, especially within their respective alliance systems

- A qualitatively greater degree of international interdependence, which refutes the purely "zero sum" (the Leninist "kto-kogo") view of international relations and highlights the impact of forms of power other than that of armed force. 
The consequences of nuclear parity, i.e., the obvious limits to the political use of nuclear weapons, which raised the question of the kind of military policy the Soviet Union, should have under conditions of both a continuing arms competition and nuclear parity.

The conclusions that the Soviet reform leadership drew from these trends have been encapsulated in the "new political thinking" on foreign and security policy, which may be summarized as follows:

* Nuclear war cannot under any circumstances be won; therefore, nuclear weapons cannot be an instrument of policy.

* Security cannot be obtained through military means alone; further more, security in the nuclear age is mutual in character and must rely strongly on political means.

* Nuclear deterrence as a durable guarantor of peace is rejected. Strategic parity, seen as a historical success for socialism, could cease to be a factor of stability in the face of an unconstrained arms race.

- Peaceful coexistence as a concept is seen less as a form of class struggle and increasingly as a long-lasting condition in which states with different social and political systems will have to learn how to live with each other for the indefinite future.

* The multipolar and interdependent character of contemporary international relations is increasingly recognized.

* Even a conventional war, fought in Europe with contemporary military technology, would be catastrophic and must be prevented.

Most remarkably, Gorbachev undertook a sweeping reevaluation of the role of ideology in Soviet foreign policy, which Western and now even some Soviet analysts view as a fixed background condition of the cold war between East and West. Gorbachev wrote that the Soviet leadership has "taken the steps necessary to rid our policy of ideological prejudice(Gorbachev 1987)."Yevgenii Primakov, a close adviser of Gorbachev, argued in a key 1987 Pravda article that peaceful coexistence is no longer regarded "as a breathing space" by the Soviets. "Interstate relations," he emphasized, "cannot be the sphere in which the outcome of the confrontation between world socialism and world capitalism is settled(Pravda 1987)."Such active coexistence is said by Soviet analysts to imply not just the simple absence of war (the cold war itself may have ensured that). Instead it implies an international order in which rather than military strength relations of confidence and cooperation prevail and global problems the arms race, ecological problems, Third World development can be resolved on a collaborative basis. This has led to a more pragmatic Soviet understanding of peaceful coexistence, with "class interests" now strictly subordinate to geopolitical criteria in the daily conduct of foreign policy. Soviet toleration of the anti-Communist revolutions in Eastern Europe, including the unification of Germany on Western terms, is the decisive confirmation.

\section{An Innovative Brim: The Spiraling and Plummet of Detente (1966-1976)}

Sardonically, as the United States escalated the war in Vietnam to contain communism, the Johnson administration deescalated conflict with the Soviets. The seeds of detente, or lessening of international tension, were sown in 19671968, at the moment United States forces suffered setbacks in Vietnam and blossomed in 1971-1972 as American bombers obliterated people and villages in large areas of Southeast Asia. Thus detente did not signal an American retreat from world affairs but was a new and necessary tactic for carrying on traditional containment policy. Overall, the power of the United States economy and military (not to mention American culture, especially music, art, and McDonald's) remained dominant on the globe. But that power could no longer influence Soviet policy or the newly emerging areas as it had before the 1960s. A new world had appeared. For a decade (1966-1976), detente became both a safety valve for releasing tension in that world and a tactic for controlling the emergence of the Soviet Union as a global power. The collapse of detente in the mid-1970s tellingly revealed how both the United States and Russia had not yet been able to come to terms with the new world.

Johnson initially pursued détente in the hope that the Soviets, who were the largest suppliers of military goods to North Vietnam, might be able to pressure Ho Chi Minh to make peace. The Americans' hope was badly misplaced. On the battlefields the war dragged on, while at home the inflation rate doubled to 5 percent and antiwar protests intensified. Johnson's beloved Great Society program, created to erase domestic poverty and injustice, became a victim of a war 11,000 miles away. A top White House official caught the President's dilemma with the remark, "What the hell do you say? How do you half-lead a country into war(McPherson LBJ Library)?"

Growing problems thus forced Johnson to approach the Soviets. Brezhnev and Kosygin were willing to talk, but not necessarily about Vietnam. Their influence in Southeast Asia increased each day the war dragged on. Unlike their late 
mentor, Stalin-whom Khrushchev once sarcastically described as thinking that "foreign policy meant keeping the antiaircraft units around Moscow on a twenty-four-hour alert(Talbott 1970)."the new Russian leaders pushed their influence into such areas as the Middle East and South and Southeast Asia. Their military power was burgeoning. After the 1956 Suez crisis, the Russians began a rapid buildup of conventional land and sea forces until by the late 1960s their fleet, once a subject of ridicule, began to appear regularly in the Mediterranean. Indian Ocean and even Caribbean areas (Mccomell \& Dismukes 1979). As for their nuclear forces, after the 1962 missile crisis a Soviet official warned an American that "you'll never be able to do that to us again." and by 1968 the Russians approached strategic parity with the once supreme American arsenal.

The Vietnam morass and the new balance of power therefore also required that Johnson deal with the Soviets. Brezhnev and Kosygin were receptive, for although the Russians' military power had sharply increased, their economic growth rate had dropped drastically in the 1960s. They needed economic relief. The Soviets, moreover, have always delighted in bargaining as an equal with the United States, a nation they simultaneously fear, dislike, and try desperately to emulate. The time was ripe for a deal.

But the first deal on Vietnam was never struck. Rusk urged the Soviets to call off their North Vietnam ally because, he warned, if Russia was "backing the north to seize the south, then we [the United States and U.S.S.R.] were in trouble," for the United States would never allow it. The Soviets responded by threatening to give Ho new surface-to-surface missiles and flatly announcing, "Since North Vietnam is a part of the Communist community; the Soviet Union must support and will assist it increasingly as the U.S. escalates its efforts(Memorandum LBJ Library 1967)."Americans acted, moreover, as if the Soviets could actually force Ho to give up his struggle; that was a highly doubtful assumption.

Johnson was luckier in his attempts to slow the nuclear race. At a summit meeting with Kosygin at Glassboro, New Jersey, an impassioned warning by Defense Secretary McNamara about the suicidal arms race both nations were running helped lead to an announcement that a nonproliferation agreement had been reached. Each power pledged to halt the distribution of nuclear weapons. Ominously, China, France, and India, among others, refused to sign the pact.

Détente seemed to be moving ahead. And then it suffered two stunning setbacks. The first began in February 1968, when the North Vietnamese launched a surprise Tet (New Year) offensive that was not beaten back until they threatened even the grounds of the United States embassy in Saigon. Until that occurred, Johnson could claim that the war was going better and Americans could see "light at the end of the tunnel." Now the light seemed to be an on-rushing freight train engineered by Ho. The North Vietnamese suffered heavy casualties during Tet, but they broke the illusion held by many Americans that the war could soon be won(McPherson LBJ Library).

Johnson consulted a group of elder statesmen, and the most famous "wise man," Dean Acheson, bluntly told the President that his advisors had led him "down the garden path." A month later, Senator Eugene McCarthy, Democrat of Minnesota, ran on an antiwar platform and nearly defeated Johnson in the New Hampshire presidential primary. On March 31, 1968, the President dramatically announced on national television that he was pulling out of the race so he could devote all his energies to making peace with Ho. Johnson turned down a military request for 206,000 more men to be added to the nearly 500,000 already in Vietnam, but he secretly allowed the numbers to rise to 549,000 . He planned to turn up the military pressure as he moved toward negotiations; if Ho refused to talk, then, as the State Department secretly informed United States ambassadors in Asia, it would "give us a clear field for whatever actions" were "required (New York Times 1971)."

At home the United States seemed to be approaching a crisis. Between 1964 and 1968 ghetto riots claimed dozens of lives in Los Angeles, Detroit, and Newark. After Martin Luther King, Jr., was murdered in April 1968, even Washington erupted in flames, as army troops moved into the city and used the Capitol Hill lawn as a bivouac area. Three major political assassinations (John Kennedy in 1963, King and Robert Kennedy in 1968; shocked the world. When the Democratic National Convention met in Chicago during the summer of 1968, massive antiwar riots broke out. Six thousand troops were flown into the city, and Johnson could not attend his own party's meeting because of the danger. Amidst the chaos, Vice President Hubert Humphrey became the party's nominee. Maine's Senator Edmund Muskie (who fought against a proposed peace resolution at the convention) accepted the vice presidential nomination.

When Republicans met in Miami, three blacks died in a ghetto riot, but the media paid scant attention. Instead the nation watched Richard Nixon arise from the political grave. His 1962 defeat in the California gubernatorial race, one liberal columnist wrote at the time, had supposedly sent Nixon "to that small place in history which belongs to national disasters which did not happen." But Nixon refused to go. By 1968 he had become the most important Republican spokesman on foreign policy. With surprising ease, he beat back the challenge of New York Governor Nelson Rockefeller (whose foreign policy speeches were largely drafted by Harvard Professor Henry Kissinger) and won the Republican nomination. Maryland's governor, Spiro Agnew, who admitted his name was not "a household word," became Nixon's 
running mate. While Nixon pictured himself, as a statesman during the campaign, Agnew took a lower road and accused Humphrey of being soft on communism.

These rapid political changes slowed down the détente process, but it was knocked off its tracks in August 1968 by a second event: the Soviet invasion of Czechoslovakia. Since the mid-1960s, the Soviets and their satellites had moved in different directions. Some Eastern Europeans experimented with more liberal economic policies. The Czechs, during their so-called Prague Spring, even discussed a loosening of their one-party political system. The United States encouraged the process by opening up trade channels. As one State Department official said, Western goods have "tended to open up more and more holes, shall we say, or windows, rather, in the Iron Curtain(Solomon LBJ Library)."

The Brezhnev- Kosygin's regime, meanwhile, stolidly and unimaginatively tightened its control within Russia. Stalin's image was refurbished, and a centralized planning system (tagged "Stalinism with computers") emphasized military and heavy industry investment. Intellectuals especially Jews were arrested, deported, or declared "insane" when they questioned governmental policies. Brezhnev, who survived an assassination attempt and became the most powerful figure in the Politburo, warned that dissent could not be tolerated because "we are living in conditions of an unabating ideological war(Leonhard 1973)." Détente meant a lessening of military and political tensions with the West, but ideological coexistence could not be allowed.

The Prague Spring strained this rigid ideological line to the limit. Soviet officials were divided over how to respond. Some Foreign Ministry officials, who did not want to endanger détente, were among those opposing intervention, but they were overbalanced by party leaders who feared ideological and economic contamination from Czech liberalism, and by some military and secret police officials who believed the Czech policies might infect the entire bloc. Brezhnev at first equivocated, but as the pro-intervention faction gained strength and threatened his own power, he joined his and ordered Soviet troops to smash the Czech regime (Valenta 1979).

He did so at the moment Johnson prepared to meet the Soviet leaders at a summit conference. The President quickly canceled the meetings. Brezhnev's willingness to sacrifice détente indicated the extent of his fear of disorder and liberalization in the bloc, as well as his keen sense of how to survive cutthroat Politburo politics. He capped the performance by issuing a "Brezhnev Doctrine" that justified Soviet intervention on the ground that a socialist nation had the right to save another from "world imperialism" and thus preserve the "indivisible" socialist system. Johnson did little in response, not only because of the military realities but perhaps also because the Brezhnev Doctrine for Eastern Europe was not unlike the Johnson Doctrine of 1965 for Latin America. Neither superpower would tolerate new ideological challenges in its own sphere.

As detente stalled, Nixon stumbled toward the White House. His 15-percentage point lead in the polls during September dwindled to less than 1 percent in the November election. Nixon was the first newly elected President in the century that failed to give his party control over either house of Congress. Throughout the campaign, he refused to take a clear stand on the war and said only that he had a mysterious "plan" to end it honorably. Privately he told aides. "I've come to the conclusion that there's no way to win the war. But we can't say that, of course." He preferred not to discuss concrete issues at all. ("You still have to put out a folder saying what you're for and against," he complained privately. "Women particularly like it. They don't have the slightest idea what it means.")(Whaleu 1972).

As usual, the election results were not a mandate on foreign policy. Despite the antiwar protests on the campuses, the pro-war third-party ticket of Alabama Governor George Wallace received more support from voters under the age of thirty than it did from the population as a whole. (Throughout the 1965 to 1073 years, the war was most firmly opposed by older, not younger, Americans; by blacks who were doing a disproportionate share of the fighting and dying, rather than whites; by females rather than males; and by lower-class rather than middle-class Americans(Lunch \& Sperlich 1979). As for the winner, Americans knew he stood for "law and order in the streets," but few knew his plans for Vietnam or detente.

Nixon, however, understood what had to be done, and he thought he knew how to do it. His plans became clearer when, surprisingly, he picked Henry Kissinger as national security advisor. Both men believed the 1970s would be shaped by developments that were sapping United States dominance in world affairs: the Soviet military buildup; the rising economic and political power of Western Europe and Japan, which threatened American markets and worked against Washington's policies in such areas as Vietnam and the Middle East; and the apparently bottomless pit of the Vietnam War.

Above all, as Kissinger liked to say, the greatest problem was how to "manage" the Soviets as they emerged as a global, instead of merely a regional, superpower. Containment was as important in the 1970s as the late 1940s, but because of the new Russian strength, and the relative decline of American power, containment now had to be constructed differently than when Acheson or John Kennedy made policy. Nixon and Kissinger believed the Soviets could be contained not by a massive arms race or increased United States global commitments (which neither the American 
public nor the economy could tolerate) but by making a deal: the Soviets could have sorely needed economic help if they cooperated in Vietnam and agreed to arms limitation.

In the new containment, Nixon also planned to open talks with China. For twenty years Mao had been the Asian villain to Americans, but since the late 1950s he had also become Russia's main concern. The realization that one communist power could be played off against the other allowed Nixon to believe that an "era of confrontation" was ending and an era of negotiations beginning (Hoffman 1979). Once the relationship between the Americans and the Soviets was properly adjusted, Nixon and Kissinger concluded, the other problems Vietnam and the Allies could be resolved.

All this required time, order, and support at home. With various devices, both legal and criminal, Nixon gained time over the next five years. He also created temporarily order and support at home. For above all else, he and Kissinger sought order and control, both at home and abroad, with an awesome single-mindedness. When once asked whether he favored a revolution with justice or an orderly state that was unjust, Kissinger quoted Goethe: "If I had to choose between justice and disorder, on the one hand, and injustice and order on the other, I would always choose the latter (Stoessinger 1976)." At home, this passion for order led Nixon to use criminal means in attempts to squelch antiwar protesters. Kissinger could not understand why college students refused to fight in Vietnam: "Conscientious objection is destructive of a society. The imperatives of the individual are always in conflict with the organization of society. Conscientious objection must be reserved for only the greatest moral issues, and Vietnam is not of this magnitude (Frichey 1969)."At that point, more than a million people had been killed or wounded in Vietnam.

This determination to have order also led Nixon and Kissinger to control policy making with an iron grip. Perhaps the President could have both directed policy and restored the public's shattered faith in government by structuring political coalitions in which his policies were debated and obtained support. In 1969 political analyst Richard Scammon thought such an opportunity existed. As ethnic and trade union voters became middle class and moved away from their loyalty to the Democrats, Scammon remarked, "There is a possibility that by following a centrist line-moderately conservative [Nixon] could build up a great new party of the center(Whitworth 1969)." Other observers proclaimed the advent of an "emerging Republican majority." Nixon might well have been able to resolve one of the great problems in United States foreign policy: how to use American political institutions to gain support from Congress and the public, instead of resorting to an Imperial Presidency that acted without public debate and too often created support through lying.

Nixon never tried to create such political institutions. Highly insecure personally, the President was "the most complete loner I've ever known," said Senator Barry Gold water. "The man operates all by himself." Carrying the scars of too many political wars, the President preferred to circumvent a Democratic Congress. Nixon did not even trust the CIA: "It was staffed by Ivy League liberals" who had always opposed him politically. As for the State Department, he believed that "no Secretary of State is really important. The President makes foreign policy (Kissinger 1979)."

Nixon consequently named William Rogers, a New York lawyer and an old political ally in the Eisenhower years, as secretary of state to keep the department quiet while the White House made foreign policy. Kissinger ensured State's impotence by keeping information from Rogers (and other cabinet members), encouraging Nixon to believe that Rogers was not a loyal team player, courting reporters and congressmen who heard only Kissinger's side of a story, and conducting critical negotiations without informing the State Department. Nixon understood all this. He remarked privately, "Henry thinks Bill [Rogers] isn't very deep and Bill thinks that Henry is power crazy. In a sense they are both right (Gelb 1976)." It was the only time in American history that a secretary of state was appointed because of his ignorance of foreign policy. But then Kissinger often did not consult even his own staff. "Henry's chief lieutenants are like mushrooms," went the joke. "They're kept in the dark, get a lot of manure piled on them, and then get canned(Mazlish 1976)."

Without assured congressional support, the trust of the State Department, or sometimes the confidence of Kissinger's staff, the President and his closest advisor had only each other. They considered this to be enough. When Kissinger was the ghostwriter for Nixon's "State of the World" report in 1970, an observer thought it resembled a message from the Vatican, except that "the Pope quote Scripture" while "Mr. Nixon quotes himself 31 times directly(Morgenthau 1970)." Kissinger meanwhile controlled the foreign policy-making process from the White House and, as the President's personal assistant, did not have to be accountable to Congress. Rogers, although knowing little about any policies, had to testify before committees in what one senator frostily called "a rather empty exercise." Instead of building political institutions, Nixon was systematically undermining them.

Despite his firm control over policy, Nixon enjoyed few early successes. He was reluctant to deal with the Soviets in the aftermath of the Czech invasion. The President knew, moreover, that he could not negotiate with Brezhnev from a position of strength until the Vietnam War and the uproar at home were brought under control. He announced in 1969 that United States troops would leave Vietnam in a phased withdrawal. This policy promised to wind down the war and end 
the antiwar protests. Nixon, however, had no intention of following what he bitterly called "isolationism." The United States must retain its global obligations, but it had to uphold them with different policies than it had during the post-1945 years when it enjoyed overwhelming power.

In Vietnam Nixon pursued a policy of "Vietnamization," that is, building South Vietnam's Army so it could replace the departing Americans. This approach actually resembled the failed policies of 1954 to 1965. As one United States official said, it simply meant "changing the color of the corpses." Elsewhere the president followed a "Nixon Doctrine." It provided that as the United States pulled back from some of its military commitments, Americans would help certain friends take up the burden of containment. In Asia the friend was to be Japan; in the Middle East, Iran; and in Africa, Zaire (the former Belgian Congo) and the white-dominated, but black majority, countries of Angola (a Portuguese colony) ant South Africa.

Nixon and Kissinger sought containment-on-the-cheap. They even planned to make a profit. Overseas sales of American military arms amounted to $\$ 1$ to $\$ 2$ billion in the mid-1960s, but they surged toward $\$ 10$ billion by the time Nixon left office. Iran alone bough $\$ 2.5$ billion of arms in 1972-1973. Nixon ordered that the shah could have the newest equipment, and all that His Majesty desired.

The shah responded by ordering planes and other equipment "as if he was going through the Sears, Roebuck catalog," in the words of one official. In all, the Nixon Doctrine encouraged a dangerous military buildup in the Middle East and southern Africa; nearly bankrupted some nations and encouraged others, such as Iran, to raise oil prices rapidly to pay for the inflation-priced United States equipment; made these nations more likely to use force rather than negotiations to settle disputes; helped create dangerously strained relations with Japan when it refused to become an Asian policeman; and caused Nixon to become a political bedfellow of the shah and white supremacist regimes in Africa. The doctrines only redeeming virtue was that it gave the President a rationale for pulling back from Vietnam.

But even that virtue was not immediately apparent. As Nixon pulled out troops, he secretly escalated the bombing, particularly in Cambodia, which although a neutral state was used by the communists to funnel troops into South Vietnam. The bombings turned out to be a catastrophe. The New York Times published a story on the "secret" bombing in March 1969. Nixon set up a "Plumbers" unit to stop such leaks "whatever the cost." This decision led to a series of criminal acts by the Plumbers that climaxed in their attempt to break into Democratic party headquarters at Washington's Watergate Hotel in 1972.

The bombings meanwhile only drove the communist forces deeper into Cambodia and destabilized the country. In early 1970 a right-wing military officer, Lon Nol, overthrew the government of Prince Norodom Sihanouk, who miraculously had kept Cambodia out of the path of the war's destruction. The United States apparently was not directly involved in the overthrow. Although the CIA certainly knew of Lon Nol's plans. But Nixon rushed to take advantage of the coup. On April 30, 1970, he announced in an emotional speech that the United States must not act as a "pitiful, helpless giant." American troops were therefore invading Cambodia to clean out the communist camps. In the name of winding down the war, Nixon expanded it(The standard account 1973).

Both Cambodia and American campuses were soon devastated. Lon Nol proved to be an incompetent partner who watched helplessly as his own ally's planes, as well as communist armies, savaged his nation. By 1971 the communists controlled half the country. (By 1975 they had all of it. More than 250,000 persons had been killed, massive starvation began, and one of the world's most beautiful countries lay in ruins.) In the United States students at-nearly 500 colleges went on strike to protest Nixon's invasion. At KentState in Ohio and JacksonState in Mississippi protesters were shot and killed. Thousands of antiwar Americans descended on Washington. Troops were stationed in the White House basement to repel a possible assault. Nixon, Kissinger feared, was on the edge of a nervous breakdown. The President would shout, "Let's go blow the hell out of them," as embarrassed aides looked on in stunned silence. But public opinion polls showed that 50 percent of the Americans surveyed supported Nixon's invasion, although 53 percent did not believe his claim that the action would shorten the war. Congress loyally acted as a lightning rod, absorbing the antiwar protesters' fury but doing nothing until they left Washington and Nixon pulled the troops out of Cambodia. Congress followed the President, not the people in the street (Shawcross 1980).

The Cambodian tragedy was one in a series of disasters that marked 1970-1971 as a nadir in recent United States history. In 1971 Nixon authorized South Vietnamese troops to clean out communist sanctuaries in Laos. "Vietnamization" turned out to be a failure as American television showed South Vietnamese troops clinging desperately to departing American helicopters in order to escape communist gunfire. Nixon responded by stepping up the bombing of Laotian supply trails until Laos became the most heavily bombed country in history. By mid-1971 the communists were in a stronger position in Laos than at any time since 1962. 
Vietnamization failed despite an enlarged war and the dropping of bombs at the rate of one ton for every minute Nixon was in office. Between 1969 and 1972, 20,000 Americans died in Vietnam, and over 300,000 Asians were killed while the war was supposedly winding down. In frustration, one popular Saigon newspaper ran a daily contest in which readers submitted stories of such atrocities as rape or homicide committed by Americans. North Vietnam, that "raggedyass little fourth-rate country," as Lyndon Johnson once called it, was tormenting the United States. Americans tired of supporting a South Vietnamese regime that was corrupt and incapable. Many were also sickened by the slaughter dramatized during early 1971 when a military court-martial convicted Lieutenant William Galley, Jr., of killing at least twenty-one South Vietnamese civilians in 1968 at the village of Mylai. It was a war in which the enemy and the civilians were indistinguishable. Meanwhile, American soldiers, unwilling to be, perhaps, the last to die in such a war, used drugs in increasing amounts to avoid combat. Over 9000 were arrested for drug use in Vietnam during 1970, and their superior officers estimated that 65,000 United States troops had used drugs(Shaplen 1970)."

And as Vietnamization failed, so too did the American economy. The gross national product (the sum of all services and goods produced) rose over the $\$ 1$ trillion mark, but an apparently uncontrollable inflation accounted for half the increase in 1971. The nation's industries, moreover, were becoming so uncompetitive that, for the first time since 1894,.Americans imported more merchandise than they sold abroad. As the economy weakened, so did the dollar the foundation that had under girded the remarkable post-1945 global trading system. In 1971 nearly $\$ 50$ billion was held abroad, and more and more dollars were being printed in Washington, and then pumped overseas, to pay for the nation's military expenditures and private investments. Overseas, dollars increased in number as they decreased in value. Europeans, watching helplessly as these dollars bought up their industries, grew angry and began to raise walls against the dollars and United States trade. "The rest of the world," French President Georges Pompidou announced, "cannot be expected to regulate its life by a clock [the dollar] that is always slow." The efficient Japanese economy sent streams of cars, steel, and electronic goods into American ports and in 1969 had replaced the United States as Asia's leading trade partner. Nixon became furious when Japan refused to stop certain exports voluntarily until the United States regained its economic health. The Nixon Doctrine, indeed the entire alliance system, was in deep trouble(Berman 1972)."

In 1970 Nixon promised he would never impose wage and price controls to stop the inflation that was making American goods more expensive than Japanese or West European products. But in midsummer 1971, the balance of payments suddenly showed the possibility of an unbelievable $\$ 48$ billion annual deficit. The dollar, and hence the Western trading structure, threatened to collapse. In a Kansas City speech, the President discussed the "five great economic superpowers" (the United States. Russia, Japan. Western Europe, China), four of whom "challenge us on every front." "Because economic power will be the key to other kinds of power in the last third of this century," he continued, and since domestic and foreign policies were so interlinked, Americans had to discipline themselves and their economy before they groveled in the "decadence" that had toppled Ancient Greece and Rome (Public Papers 1972).

In August 1971 the President suddenly imposed a wage-price freeze to curb inflation. He also placed surtax on foreign imports to stop the inflow of goods from Europe and Japan, a nation that as a State Department briefing paper reportedly warned Nixon-must be viewed as a potential enemy. He and his secretary of the treasury, tough-talking Texan John Connally, put tremendous pressure on the Allies to revalue their currency while the United States devalued the dollar, thus making the dollar cheaper and more competitive in world markets. Finally, Nixon announced the dollar would no longer be redeemable in gold. The French bitterly called this program "a Marshall Plan in reverse." Unfortunately, it was not enough. In 1973 the economy and the dollar again began slipping after Nixon removed the wage-price freeze. The dollar again had to be devalued. As in 1807, 1893, and 1914 a failing economy forced the United States to change its foreign policies. The era of the all-powerful dollar temporarily ended, and with it went much of Washington's political power (and the good times abroad once cheaply enjoyed by American tourists).

A year before the 1972 presidential campaign began. Nixon was plagued with troubles. Then occurred a remarkable turnabout. The wage-price controls temporarily halted inflation. The economic picture brightened, albeit at the expense of the Allies. The military draft was cut back and student antiwar protests disappeared as if by magic. But most dramatically, in July 1971 Nixon seized the diplomatic initiative with the startling announcement that he would be the first President to visit China.

Since 1969 the two nations had sent subtle signals encouraging a new relationship. Nixon and Mao hoped to use the other to check Soviet power. China's fear of the Russians jumped in 1969-1970, when nearly 1 million Soviet soldiers encamped in a broad area along the Sino-Soviet border. Clashes occurred with Chinese troops. Nixon also hoped to develop a China market so American businessmen could find economic relief and enter China before the Japanese locked up the most promising trading ventures. Mao was receptive. 
The President's major problem might have occurred at home; where for thirty years an anticommunist "China Lobby" had worked, often with Nixon's help, to make Americans believe that Chiang Kai-Shek's government on Taiwan, not Mao's, was the real China. Opposition did develop, particularly from the American Federation of Labor, but the President enjoyed wide maneuvering room. A mid-1960s poll showed that about 25 percent of Americans were unaware that China even had a communist government (Hughes 1974).Nixon, moreover, could not be charged with being soft on communism. He had made his political reputation with such remarks as calling the 1952 Democratic presidential nominee. Adlai Stevenson, "the appeaser who got a Ph.D. from Dean Atchison's College of Cowardly Communist Containment." In 1971 politicians resembling the earlier Nixon did not threaten Nixon.

His 1972 journey to Peking was a huge success. A friendship treaty was signed; trade opened up, the Soviets were made fearful of a possible Sino-American alliance, and within months the Chinese entered the United Nations while Chiang's delegation was expelled. (Chiang died in 1975. the last survivor of World War 11's "Big Four." United States officials increasingly considered Taiwan as an internal Chinese problem, and by 1980 China and Taiwan were cooperating on some economic policies.)

The China trip and the slowing down of the Vietnam War placed Nixon in a position to travel to Moscow. He became the first President to visit the Soviet capital. Before his scheduled trip was due to begin in mid-1972, however, the North Vietnamese launched surprise attacks that threatened to overturn the South Vietnam government. Nixon, already called the "biggest bomber in world history," responded with intensified air attacks. In a dramatic departure called "Operation Linebacker" (the President was a devoted football fan), American planes bombed and sowed mines in the vital North Vietnam ports. Lyndon Johnson had refused to mine the ports; he feared Russian and Chinese ships would be hit and the war escalated to a big-power crisis.

Nixon, however, believed he had to show American toughness as American troops left Vietnam and the presidential campaign approached. "Look," Kissinger later explained, "it wasn't just a matter of this summit his political ass was on the line." Kissinger talked tough with the Soviets. Although the war destroyed Johnson, he informed them, "Nixon will not permit three Presidents in a row to leave office under abnormal circumstances (Safire 1975)." Then he tossed in the bait. Politics and economics had always been closely related in Russian-American relations, Kissinger noted. If the Soviets wanted economic help, they must cooperate politically. This "linkage" was a key to the summit's success.

Nixon calculated correctly. Regardless of events in Vietnam, the Soviets wanted to negotiate. Their readiness had been announced at the Twenty-fourth Party Congress in 1971 when Brezhnev presented a "peace program" that shaped Soviet views, especially detente policy, through the 1970s. Brezhnev's 1971 program rested on four logs, but only one of these was strong.

The strong leg was the military. In his era, Khrushchev had tried to expand Soviet influence primarily through Russian economic successes and taking advantage of revolutionary situations in newly emerging areas. The plodding Brezhnev held no such illusions; the economy was in trouble and most revolutionaries mistrusted heavy-handed Russians. Brezhnev instead placed his faith in a large buildup of military power. He increased defense budgets at a steady 3 percent annually (while the United States cut its post-Vietnam military) and drafted every able male at the age of seventeen for two-year active service and reserve service until the age of fifty. A force of 5 million stood at the ready. Brezhnev planned to wield it as a diplomatic weapon to obtain political dividends, especially in negotiations with the United States. Americans now had to deal with him as an equal superpower. For his part, he badly needed their help to prop up the other three, weaker, legs (Helmut \& Hyland 1979).

One was Eastern Europe. Despite the Czech tragedy of 1968, the satellite states, particularly Rumania and Poland, slowly evolved national policies that did not fit the Russian model. The area was in a greater state of flux, and being more drawn to the booming Western economies, than Moscow desired. In a crisis the bloc could be controlled by force; that was one reason for the Russian military buildup. But the army could not resolve the deeper problems. In 1971 Brezhnev therefore made a deal in which the West Germans finally recognized the Eastern European boundaries imposed by the Red Army in 1945; in return, he settled the long-festering Berlin question by guaranteeing Western access to the city. He now wanted Nixon to agree to that arrangement and thereby further stabilize the weak leg.

The second wobbly leg was Sino- Soviet relation. This problem was indeed so dangerous that it provided a central reason for the military's expansion. The fear of "encirclement" that had haunted earlier Soviet leaders now reappeared, especially after the Chinese opened talks with Japan and the United States. Brezhnev designed his detente policy in part to ensure that it would remain in Nixon's interest to deal with him instead of moving closer to Mao.

The leg that needed the most support was the Soviet economy. The five-year plan of 1966-1970 had failed to reach its objectives. Despite, or because of, decades of coercion, Russian farm workers were only one-sixth as 
productive as the Americans. Brezhnev wanted United States technology and agricultural products. A mammoth wheat deal, part of a larger trade agreement worked out at the summit, nearly doubled Soviet-American trade. Unfortunately, the Russian negotiators outfoxed their capitalist counterparts, bought the wheat at bargain-basement prices, and helped create a grain shortage in the United States that worsened inflation. To Nixon and Kissinger, however, the "Great Grain Robbery" was a cheap price to pay. They opened new markets for American farmers while reaping diplomatic benefits.

Given, therefore, the economic problems of both nations, and their need to bring spreading military commitments under some control, Brezhnev as well as Nixon designed a detente policy. The two leaders signed a Strategic Arms Limitation Treaty (SALT I). The pact ended the race to develop a defensive antiballistic missile system (ABMs) that promised to be enormously expensive and highly ineffective. SALT I also froze the number of nuclear missiles so the Soviets had no more than 1600 and the United States 1054. Those numbers, however, deceived. For the United States had developed a new monster weapon, the MIRV (multiple independently targeted reentry vehicle) that contained on one missile multiple warheads capable of hitting widely separated areas. With the MIRV, Americans enjoyed a 2 to 1 lead in deliverable warheads another good reason why Brezhnev wanted an agreement that limited the number of missiles. One American submarine possessing MIRVs was capable of inflicting 160 Hiroshima blasts. The United States had over thirty such subs. The Soviets moved rapidly to deploy their first MIRV in the mid- 1970s. SALT I therefore only placed a few limits on, but did not stop the arms race.

The summit was a triumph for both Brezhnev andNixon.The Russian leader successfully carried out his detente program announced at the Party Congress. In Vietnam the communist offensive ground to a Holt; the Chinese and Russians did little publicity to retaliate for the United States bombing and mining. Nixon'spolicy had worked.

During the 1972 campaign, the Democratic nominee Senator George McGovern of South Dakota never had a chance. His left-of-center politics alienated many Americans and left him open to the unfair Republican charge that McGovern was the champion of "amnesty [for men who had illegally avoided the draft], acid, and abortion." He presented a carefully prepared foreign policy program that urged an immediate withdrawal from Vietnam and a sharply reduced defense budget. But McGovern could not stir up a debate. As Nixon isolated himself in the White House. Republicans accused McGovern of following an "isolationist" foreign policy. When the Democratic nominee pointed to the Watergate break-in and claimed the Nixon administration was the most politically corrupt regime in American history, the voters were unmoved. Playwright Arthur Miller observed that Americans tend to respond to calls for righteousness when they think it is also a call for lunch. The President won reelection by the second largest electoral vote margin in twentieth-century American history.

Kissinger enhanced the margin by announcing just days before the voting that "peace is at hand" in Vietnam. The celebration, however, proved premature. Kissinger had reached agreement with the communists, but he could not convince South Vietnam's President Nguyen Van Thieu to accept terms that allowed large numbers of communist troops to remain in South Vietnam. The deal collapsed. After the election Nixon began the most devastating bombing attack yet launched on North Vietnam. Parts of the country were carpet-bombed. Congress watched, nearly 60 percent of Americans polled supported this "Christmas bombing," and no one stopped the President. As one journalist recorded Nixon's private conversation, he "did not care if the whole world thought he was crazy for resuming the bombing," for "the Russians and Chinese might think they were dealing with a madman and so better force North Vietnam into a settlement before the world was consumed in a larger war(Hughes 1974)."

Tragically, however, it was South Vietnam that held up a peace treaty. Nixon finally won Thieu's agreement with huge amounts of supplies and a secret letter assuring Thieu that if he would "go with us, you have my assurance of continued assistance in the post-settlement period and that we will respond with full force should the settlement be violated by North Vietnam(The N.Y. Times 1975)." So assured, Thieu agreed. The treaty was signed in February 1973. American prisoners of war returned home. The United States had terminated its longest conflict.

Nixon stood unchallenged at the peak of his power. Free of the Vietnam quick sands, and with the Russians apparently better "managed" by detente and linkage, the President turned to other foreign policy problems. Kissinger grandly announced that 1973 was to be the "year of Europe" that is, the United States would now deal with the increasingly bitter Western European Allies to whom it had paid little attention while making momentous deals with China and Russia. Critics, who believed the Western alliance was beyond repair, remarked that Kissinger's phrase resembled the words of a long unfaithful husband who grandly announced this was to be the "year of the wife."

In the Western Hemisphere, Nixon dealt with the Chilean government of Salvador Allende, a devoted nationalist and sometime Marxist who, since his election to the presidency in 1970, had moved to break Chile free from its dependence on large landowners and American multinational corporations. Allende nationalized nearly $\$ 1$ billion of American investment. At least one multinational, International Telephone and Telegraph (ITT), urged Nixon to get tough. 
The President did so, but not primarily because of ITT. He and Kissinger viewed Allende's Chile as a potential Soviet satellite, a second Cuba, whose infection could spread through the hemisphere and demonstrate that Nixon was too weak to secure his own backyard. With the help of the CIA and close ties between the United States and Chilean military, Kissinger systematically undermined the Chilean government. Allende lost control of his nation's economy. "We set the limits of diversity," Kissinger bragged, and in September 1973 Allende died as Chile's army seized power. The military established a brutally repressive regime. When the United States ambassador protested the torture methods, Kissinger ordered him "to cut out the political science lectures(Morris 1977)."

Nixon also moved to-control, or intimidates key parts of the federal government. He gained some of this power through illegal wiretapping, breaking and entering, and misusing campaign funds. Kissinger passed all this off with the joking comment, "The illegal we do immediately; the unconstitutional takes a little longer." But a fundamental question remained: Could American foreign policy be drastically changed, and a public consensus built to support new policies, without an Imperial Presidency that distorted the truth and manipulated the people? The Nixon presidency did not provide a happy answer to that fundamental question. Even Kissinger was apparently not safe. The daring diplomat, winner of a Nobel Peace Prize for his role in ending the Vietnam War, the man with the German accent and gravy like voice "Sauerkraut" as he was happy to be called was popular and powerful. Rumors spread in Washington that a jealous President was prepared to fire Kissinger. Then in mid-1973 Congress began hearings on the Watergate break-in of 1972. Nixon's political career and American foreign policy suddenly changed. A new era was about to begin.

The most dramatic event in this new era occurred when Richard Nixon became the first American President to resign from office. That historic turn had begun when he tried to cover up the break-in by his Plumbers unit at the Watergate hotel complex in 1972. But his foreign policy also hastened his exit. In 1973 Congress and public opinion so turned against his brutal bombing of Southeast Asia that the House and Senate finally ordered an end to the attacks(Bundy 1979-80).Resembling other Presidents, before and after, who found themselves becoming mired in political trouble at home, Nixon tried to save himself with foreign policy spectaculars. Instead of firing the popular Kissinger as he had planned, the President named him secretary of state in the autumn of 1973. The two men then flew to Moscow for another highly publicized summit meeting. But it was too late; the House prepared impeachment articles, Nixon grew increasingly unstable and, since his finger remained on the nuclear button, increasingly dangerous. In August 1974 his aides and several Republican leaders convinced him to resign.

The Imperial Presidency had collapsed. In its place arose what some worried observers called an Imperial Congress. The legislature had repealed the Gulf of Tonkin Resolution in 1971, and by 1974 it had passed measures preventing American troops from reentering Vietnam. The House and Senate similarly outlawed military involvement in parts of Africa without their explicit consent. In 1974-1975 the Senate struck at the heart of Kissinger's detente policy by attaching conditions to the Soviet-American trade treaty that made the pact unacceptable to the Soviets. (These conditions included the widely discussed Jackson-Vanik amendment demanding that Moscow allow more Jewish dissidents to leave Russia if they wished, and more important from the Soviet view-a Stevenson amendment sharply limiting the amount of money the stumbling Russian economy could borrow from the United States.)(Congressional Record 1978).

Apart from these rifles like limitations, Congress used a political shotgun in its attack on presidential powers. The War Powers Act of 1973 required that "in every possible instance" the President must consult with Congress before sending troops into hostilities; when the President commits the forces, he must send a full explanation to Congress within two days and he must withdraw the forces within sixty days unless Congress expressly gives him permission to keep them in battle. The act, in reality, gives the President the power to wage war for sixty days without congressional approval, a power that the founders wisely did not give the chief executive in 1787. Congress hoped, however, that the law could prevent future Vietnams. Kissinger was furious. He warned that perhaps Congress could deal with domestic issues but, because of its super sensitivity to public opinion and interest groups, it was not designed to carry out longterm foreign policies. When his plans for Vietnam and Africa failed during 1975-1976, the secretary of state blamed Congress and the effects of Watergate. He apparently did not understand that his and Nixon's foreign policies in Southeast Asia between 1969 and 1973 had caused congressional anger and the Watergate scandal. He also failed to understand that by the mid-1970s congressional authority grew precisely because of legislative power in domestic affairs, for domestic and foreign policies were becoming one.

That intimate relationship became dramatically clear in 1973-1974 when Americans found themselves short of gasoline at home because of a war in the Middle East. An Arab-Israeli clash was, as usual, the eye of the conflict. After the Suez crisis of 1956, the Soviets had rebuilt the Egyptian Army while the United States helped make Israel the most powerful military force in the area. In 1967 the Egyptians threatened the Gulf of Aqaba, the entranceway to Israel's key 
southern port of Elath. On June 5 Israel suddenly struck. In a six-day war the Israelis drove the Egyptians back across the Suez, the Jordanian Army across the Jordan River, and the Syrians away from the strategic Golan Heights. Israel seized the old city of Jerusalem.

The United States and Russia did not intervene, but within months each helped replace its ally's stores. As the Soviets established port bases in Egypt, a confrontation loomed between the two superpowers. The new Egyptian president, Anwar el-Sadaat, proposed negotiations, but only after Israel withdrew from lands taken in 1967. The Israelis, after having paid a heavy toll for their withdrawal from the Sinai Peninsula following the 1956 war, refused Sadaat's conditions and rejected United States pressure to withdraw from all occupied territories. In October 1973, on Yom Kippur, the holiest day in the Jewish calendar, the Egyptians and Syrians launched a sudden attack that drove the Israeli Army back in a surprising show of strength. The shocked Israelis counterattacked, surrounded the Egyptian Army in the Sinai, and threatened to open all of Egypt to invasion. Sadaat appealed to Brezhnev. The Soviets mobilized troops for an airlift into the Middle East.

Kissinger \& Nixon warned Brezhnev to stay out of the area. They were warning by putting the nations nuclear strike forces on alert. But the Americans also offered the olive branch. They demanded an Israeli cease-fire and the supplying of the surrounded Egyptian forces. Kissinger held back military supplies needed by Israel until it agreed with his demands. With fresh support from Sadaat, who had expelled all Soviet military advisors from Egypt when they seemed to threaten his own power, Kissinger began a series of trips among Middle East capitals to work out a settlement. Despite two years of exhaustive efforts (his plane was tabbed the "Yo-Yo express" because it went up and down so often), the secretary of state worked out a cease-fire but could not find the key to a full settlement. His diplomacy focused on two objectives. He wanted peace, but without Soviet participation. Resembling the nineteenth-century British statesmen he had studied as a historian, and also resembling Acheson and Dulles, Kissinger determined not to allow Russian strength to shape affairs in the Middle East. He also sought to end the danger that the Arabs might try to blackmail the West. This nearly occurred in 1973. When the United States supplied weapons to Israel, using NATO bases in Western Europe as transport points, the Arab-dominated Organization of Petroleum Exporting Countries (OPEC) imposed an oil embargo that threatened to strangle the Western and Japanese economies. OPEC consisted of thirteen nations, including seven Arab countries, Iran, and Venezuela. It had been formed in 1960 to protest attempts of major oil companies (mostly owned by Americans, British, and Dutch) to reduce oil prices and payments to the producers. By the early 1970s the great international companies suddenly faced a unified bloc of producers. OPEC forced the companies to increase payments drastically, quadrupled the price of oil by 1974 to nearly $\$ 12$ for a forty-two-gallon barrel, threatened nationalization of the companies' properties, and firmly believed that "we are the Masters (Breckenfeld 1971)." Amidst a sudden energy crisis. New York Stock Exchange shares lost $\$ 97$ billion in value in six weeks.

Japan and Western Europe began switching from pro-Israeli to pro-Arab policies. This change further strained the alliance system, for the United States, which imported only 12 percent of its oil from the Middle East (compared with 80 percent for the Europeans and over 90 percent for Japan), remained staunchly committed to Israel. As the Allies changed, Kissinger bitterly commented that they were "craven" and "contemptible (Washington Post 1974)." Not only had hopes for the "year of Europe" turned to ashes, but he believed that Western Europe had become his "deepest problem."

The energy crisis would have occurred in the not distant future regardless of the Arab-lsraeli conflict. Between 1945 and the late 1970s, the West and Japan consumed more oil and minerals than had been used in all previous recorded history. With 6 percent of the world's population, the United States used nearly 40 percent of that wealth (Barnet 1980). The West could not continue to increase its energy use 5 percent annually, pay low oil prices, yet sell inflationpriced goods to the petroleum producers. This was emphasized by the shah of Iran, whose nation was the world's second-largest oil exporter, and who was Washington's most trusted Middle East friend, according to the Nixon Doctrine. "Of course [the price of oil] is going to rise," the shah declared. "Certainly! And how! You [Westerners] increased the price of wheat you sell us by $300 \%$, and the same for sugar and cement. You buy our crude oil and sell it back to us, refined as petrochemicals, at a hundred times the price you've paid to us. It's only fair that, from now on, you should pay more for oil. Let's say 10 times more (Akins 1973)."

The Nixon-Kissinger policies were falling apart. They had focused on Russia and China, but the challenge now came from the Third World. American power was even under attack in Latin America, an area Kissinger had supposedly once dismissed as "a dagger pointed at the heart of Antarctica." The Republicans devised no alternative to the moribund Alliance for Progress. As terrorism and guerrilla activities increased, Nixon's only major response was to propose doubling the amount of military arms sold by the United States and, in Chile, helping a military regime replace Allende. But Allende's overthrow did not remove a more fundamental danger. In 1975 the secretary of state worried that Latin Americans and other newly emerging nations were "tending to form a rigid bloc of their own," a development "particularly 
inappropriate for the Western Hemisphere (Deptt. Of State Bulletin 1975)." Again his big-power diplomacy was being undercut by the Third World. Again the energy crisis made the challenge possible, for the Latin American bloc was organized and financed in large part by Venezuela and its oil revenues, which quintupled between 1970 and 1975. A similar danger appeared to the north. Canada's television, periodicals, banks, and half its industry were dominated by the United States. Canadians began playing their own balance-of-power game. Trade was opened with China. Pierre Trudeau became the first Canadian prime minister to travel in the Soviet Union, signing consultation and trade pacts with the Russians. In 1973 strict controls were placed on foreign investments for the first time. During the 1970s exports of Canadian oil and natural gas, upon which large sectors of the United States depended, rose dramatically in price, and then exports were cut back so Canadians themselves could be assured of long-term cheap energy. While Kissinger searched for new relations with the four major blocs, hemispheric unity, which Americans tended to take for granted, fragmented.

In the Western Hemisphere and Middle East, United States officials could at least be relieved that the Soviets were not directly involved in the new developments and did not immediately profit from the American troubles. In Africa, however, the superpowers nearly confronted each other in a crisis that typified the new Cold War that was developing in the 1970s.

Since 1970, Kissinger had assumed that the Portuguese, through their colony in Angola, would help maintain stability in Africa (Westport 1976).In 1974, however, the forty-year dictatorship in Portugal fell. Angola became independent and black revolutionaries vied for power. The Americans and Chinese supplied one faction, while the Soviets backed the group that ultimately won, the Popular Movement for the Liberation of Angola (MPLA). Most startling of all, the Russians flew thousands of Cuban troops into Angola in a move that Kissinger condemned as a dangerous escalation of the Cold War. He asked Congress for massive aid to stop this Soviet aggression "by proxy," but the legislators flatly refused to become immersed in a possible Vietnam-like conflict in Africa. The MPLA triumphed and then, in a wondrous turn of events, used the Cuban troops to protect the American-owned Gulf Oil refinery (one of the nation's most important facilities) and turned increasingly to Washington for technological help. Both superpowers were learning how little Africans cared about a Cold War that seemed to obsess some Americans and Russians.

But Kissinger did not draw that lesson. He believed that Americans, especially the young who "have been traumatized by Vietnam as we were by Munich," lacked the will to stand up to the Soviets (Speech 1975). His concern increased in 1974-1975, when the United States sunk into its worst economic recession since the 1930s. He had hoped to use the nation's economic power to "manage" the Russians. Congress, however; had already undercut the 1972 trade treaty, and in 1975, when Kissinger tried to use an embargo on wheat exports as a weapon to make the Soviets behave in Africa, a tremendous uproar of protest from American farm communities forced him to back down. He reflected on how difficult it was for policy makers to protect what they considered to be the national interest, when that job had to be done in a private enterprise economy (Remarks in Los Angeles 1976).

American foreign policy improved little after Gerald Ford replaced Nixon in August 1974. Appointed by Nixon to be Vice President after Spiro Agnew had to resign for taking illegal payments, Ford had been a leader in the House of Representatives. But he had little personal prestige and no background in foreign policy. When he made a serious error while discussing the Middle East, one journalist passed it off: "What the hell, it was just Jerry talking about things he doesn't understand(Reeves 1975)."

Ford became President as Vietnam was finally falling to the communists. The agreement that Kissinger negotiated in 1973 with North and South Vietnam had never worked. President Thieu attacked the communists emplaced in South Vietnam, and in late 1973 they began retaliating. Thieu's forces lost more soldiers in 1974 than during the height of the fighting in 1967. At the same time a recession-ridden United States cut its aid from $\$ 1$ billion to $\$ 700$ million. In early 1975 the South Vietnamese Army began to disintegrate. Thieu called for President Ford to provide the American "full force" promised by Nixon in 1973. But Nixon's 1973 promise was of no effect. He and Kissinger had not made the letter public (indeed, Kissinger publicly denied in 1973 that any secret understandings existed), and Congress had prohibited the reintroduction of American forces in Vietnam. In April 1975 South Vietnam fell into communist hands. The thirty-year war was over.

Kissinger asked Americans to put Vietnam behind them-a strange request coming from a former history professor, for the lessons to be learned were many and critical. The war demonstrated that militarily the United States could not single-handedly defeat nationalist movements in Asia. Nor did it have the economic and social resources to fight such a long, inconclusive war. The United States bore great responsibility for the downfall of South Vietnam. The involvement was not comparable to American responsibility for China in the 1940s. The governments of both South Vietnam and Cambodia were Washington's creations. Both depended upon the United States for their existence. Both collapsed after 
the American forces withdrew. In this sense, the "domino theory" actually worked. (Dominoes is a game in which the pieces are laid flat. It requires special effort outside the rules to set them upright so they can collapse.) American Presidents, supported in the early years by Congress and public opinion, made a mighty effort to prop up the dominoes in Southeast Asia, and the collapse duly occurred.

Ford and Kissinger tried to reinvigorate foreign policy (and Ford's hopes for the 1976 presidential race) with two dramatic acts. They traveled to Russia in late 1974 and agreed with Brezhnev on the outline for a SALT II agreement that set new limits on nuclear arms. The other drama occurred in May 1975, when Cambodian naval units seized an American cargo ship, the Mayaguez. The seizure occurred just after Vietnam fell, OPEC had quadrupled oil prices without an American response, and Kissinger had been unable to stop the MPLA in Angola. In this political climate, Ford, with Kissinger's strong encouragement, did what Presidents have often done in similar situations: he used military force to show that he was decisive and not afraid to get tough with communists. Unknown to Ford however, the Cambodian government had released the thirty-eight crew members. Forty American troops were killed in a needless raid on Cambodian territory. Public opinion polls nevertheless showed strong support for the President's use of military force.

The Mayaguez"rescue" and the arms agreement were not enough to save Ford's campaign in 1976. Indeed, Kissinger's foreign policy became an issue. Right-wing Republicans attacked détente until Ford outlawed using the word in his speeches. Kissinger remarked that detente "is a word I would like to forget(Deptt. Of state Bulletin 1975)." Soviet activities in Angola and Cuba, and continued repression of dissidents within Russia, had soured many Americans on the idea that detente could work. Meanwhile, the Democratic nominee. Jimmy Carter, hit Kissinger from the liberal side for being too secretive, supporting dictatorial regimes, and arguing for higher defense budgets. In a style that was typical of Carter, he then blasted the administration from the other direction for giving away too much in the arms talks, and especially for Kissinger's work in the 1975 Helsinki agreements. At Helsinki, Finland, thirty-five countries, including the Western nations, accepted the East European boundaries as permanent; in return, the Soviets pledged to follow a more liberal human rights policy. Carter condemned the deal for not doing enough to protect individual liberties inside Russia(Plotkin 1977).

The Democratic candidate took different sides on so many issues that unfriendly critics charged that Carter's image could never be carved in stone on Mount Rushmore because there was room on the monument for only one face. But his tactics worked. He lost most of his 30 percent lead over Ford in polls taken during late summer but held on to win by a slim popular vote.

Carter's triumph brought a remarkable decade to an end. Between 1966 and 1976 Americans had roller-coasted from heights to depths: from near victory in Vietnam to embarrassing defeat; from a powerhouse economy to a thief like inflation; from an Imperial Presidency to the presidential humiliation of Watergate and the War Powers Act; from cheap gasoline to bending before demands of OPEC oil producers; from condemning Chinese communism to cooperation with it; and, most important, from detente to increasing confrontation with the Soviet Union. United States power to deal with the new post-1960s world had dwindled, but frustrated Americans decided that "managing" the Soviets through detente had been a failure. The question now became whether a better approach could be devised. Jimmy Carter and Ronald Reagan were to give quite different answers to that question.

\section{Conclusion}

The United States understood to think that the Soviet Union's spreading out endangered the under developed world. Accordingly, in 1949 President Truman and Congress permitted to approve just about $\$ 400$ million in favor of technological improvement curriculums in Latin America, Asia, and Africa. The prospected aim of this Point Four Program was to bring up to date and make stronger the nations those are developing yet, and dishearten the intensification of communism.

Gorbachev's course of action of Glasnost got rid of the authoritarian expurgation experienced for hundreds of years. Glasnost intends for openness, and Soviet populaces were at the moment permitted to verbalize candidly regarding their country's tribulations. Perestroika, or "restructuring," was Gorbachev's endeavor to stop the incompetence and unpleasantness in administration and managed supervision.

The US and supplementary Western realms determined to structure coalitions and alliances alongside probable Soviet shots to make bigger their globe of sway and influence. In April 1949 the United States signed the North Atlantic Treaty. Associates approved that an assault on one of them would be well thought-out an attack on the entire world to which all of them belong. The Soviets afterward fashioned a conflicting federation known as The Warsaw Pact. Because of the arms race several states in the world nowadays have possession of nuclear weapons. 


\section{References}

Acheson D., (1969) "Present at the creation: My years in the State Dept." N.Y: Norton, P. 356.

Akins J. E.,(1973), The N.Y Times, Sep 12,P. 64 for the background, "The Oil Crisis: This Times the Wolf Is here, Foreign Affairs, LI (April 1973): PP. 470-472.

Bundy M.,(1979-1980) "Vietnam, Watergate and Presidential Powers," Foreign Affairs LXVIII, Winter: PP.397-404.

Barnet R.,(1980) "The World Resources," The New Yorker, April 23,PP. 45--47; Washington Post, Feb 24,1975,P.1.

Berman L.,(1972) "How to tell where the U.S. Is Competitive, "Fortune, LXXXVI, July, PP.54-55.Seymour Melman, The Permanent war Economy (N.Y 1974), PP.112-116; Washington Post, May 27,1971 P. A27.

Breckenfeld G.,(1971), "How the Arabs changed the Oil Business, "Fortune LXXXV, August, PP.113-117.

Congressional Record, July 26, 1978, P.S11874; Rabert Bernstein, "Human Rights and the U.S-USSR Trade Crisis of 1972-1974: Another View," Unpublished paper, 1978.

Dashichev,(1988) op.cit; and pt. ten of party conference theses, Pravda, May 27 ,P.1.

Department of State Bulletin, March 24,1975,PP. 365-367.

Dept of state Bulletin, Dec 1,1975,PP.766-767.

Frichey C.,(1969) "The New York Review of Books", Sep 25, P.26.

Gorbachev M.S,(1987),Perestroika: New thinking for my country and the world, N.Y: Harper and Row, P. 250.

Gelb L.,(1976) "The Kissinger Legacy," The N.Y Times Mag.Oct 31, ,PP. 78-82;William Shawcross, Sideshow (N.Y 1979) P. 103.

Hoffman S.(1979) "For the New containment policies, ," The case of Dr.Kissinger,"The New York Review of Books, Dec 6, P. 24 and I.F Stone," The Flowering of Henry Kissinger, "The New York Review of Books, Nov 2,1972,P. 26.

Helmut S. and Hyland W. G., (1979) , Soviet Perspectives on security, London, PP.16-18; Robin Edmonds, Soviet F Policy, 1962-1973 (London, 1975) Ch. 8\&9.

Hughes B.B.,(1974), The Domestic context of American Foreign Policy, San Francisco,P. 57.

Hughes T. L., (1974) "Foreign Policy: Men or Measures Atlantic Monthly CCXXXIV, Oct: 56;Seymour Hersh, The Price of Power (N.Y, 1983) Ch.39.

Kissinger H.,(1979), White House Years ,Boston, P. 11;Whalen, Catch the Falling Flag, PP.253--256,and Washington Post, Oct $17,1976, P .4$.

Leonhard W.,(1973) "The Domestic politics of the New Soviet F.Policy,"Foreign Affairs, LII ,Oct, PP.59--75; John Dornberg, Brezhnev, The Masks of Power (New York, 1974) Chapter $15 \& 16$.

Lunch L.W. and Sperlich W.P.,(1979) "American public opinion and the war in Vietnam," Western political Quarterly, XCIV (March 1979): PP.21-44;Richard M.Scammon and Ben J Watenberg.The Real Majority (N.Y, 1970) PP.38--49and 9293.

McPherson H., "Oral History Interview, Tape\#4,P. 20,Lyndon B.Johnson Library, Austin, Texas. (Hereinafter cited as LBJ Library).

Mccomell J.M and Dismukes B.,(1979), "Soviet Diplomacy of Force in the Third World," Problem of Communism, XXVII, JanFeb., PP.15-21.

Memorandum of Conversation between Rusk and Ambassador Anatoly F. Dobrynin, May 26,1966,White House Confidential file(Asia),Box 7,LBJ Library; USSR;LBJ Library;Menorandum of conversation between Zbigniew Brzezinski and Yuri Zhukov,April 13,1967,National Security File, Country File USSR,LBJ Library.

Mc Pherson Oral History, Tape\# 9,P. 10,LBJ Library.

Mazlish B.,(1976) "Kissinger" ,N.Y, P. 231.

Morris R., (1977), Uncertain Greatness, N.Y, P. 241; The N.Y Times, March 6, 1975,P. C37.

Morgenthau H.,(1970)"Mr. Nixon's F.Policy,"New Republic March 21,P. 23.

New York Times, (1971), The Pentagon papers, published, N.Y, PP. 622-624.

Plotkin H. A.,(1977) "Issues in the 1976 Campaign." In Gerald Pomper,ed;The election of 1976, N.York,PP.50-54.

Public Papers of the Presidents-Richard Nixon-1971 (Washington, 1972), PP. 806-814.

Pravda,(1987), July 10, ,P. 4.

Remarks in Los Angeles, Feb 2,1976,Dept of state Bulletin, March 1,1976,P. 272

Reeves R.,(1975), A ford Not a Lincoln ,N.York, PP. 174,181,200.

Stillman E. and Pfaff W.,( 1961), "The new Politics: America and the end of the post war World", N.Y: Harper Colophon, P. 32.

Solomon A., "Oral History Interview, LBJ Library".

Stoessinger G. J.,(1976) "Henry Kissinger: The Anguish of Power, N.Y, PP. 12-16.

Shawcross, Sideshow PP.152-153; Marie Gottschalk "Bring Us Together: Congressional Reaction to the Invasion of Cambodia, 1970,"Unpublished honors thesis Cornell, 1980,PP.54, 72-74.

Speech of April 17,1975,Dept of state Bulletin, May 5,1975 P.560. 
Shaplen R.,(1970) "Letter from Indo-China," The New Yorker; May 16,P. 125.On drug use, The N.Y Times, Jan 11,1971,P.13. Safire W.,(1975), Before the Fall, Garden City, N.Y, PP.434-438, 452-453.

Talbott S.,(1970) "Nikita Khrushchev Remembers, translated and edited, Boston, PP. 392-393.

The Best background and the key document are in MohammadA.El-Khawasand BarryCohen,eds;NSSM39:TheKissinger study of the Southern Africa (Westport,Connecticut,1976)

The standard account is Shawcross, Sideshow especially PP.102-121 Kissinger and Nixon quotes to be found in The N.Y Times, Dec 9, 1973, P. 76 Washington post, Feb 19, 1974, PP. 1, 12-14.

The N.Y Times, May 1,1975,P. 16.

Valenta J.,(1979) "The Bureaucratic Politics Paradigm and the Soviet Invasion of Czechoslovakia, "Political Science Quarterly, XCIV, Spring, PP. 55-76.

Whaleu J. R.,(1972), "Catch the Falling Flag, Boston, PP.137-154.

Whitworth W., (1969) "Profiles, "The New Yorker, Sep 20, P. 52.

Washington Post, March 17, 1974, P. A12. 